\title{
Articles
}

\section{The value of accreditation of journalism programmes: A New Zealand perspective}

\section{ABSTRACT}

Doubts have been raised in both the United States and the United Kingdom about the merits of accrediting university-based journalism programmes. The accrediting agencies in those countries have been accused of being inflexible and focussing on the old world of print journalism. Accreditation of the three university-based journalism programmes in New Zealand has been through a similarly controversial period, but recently a new accord was reached allowing for a more flexible, non-intrusive form of accreditation. This article discusses how this new regime developed. It notes that the new accord is based on three main factors - the importance of accreditation to the journalism programmes, the power relationships existing between the accrediting agency and the schools, and the personalities of those involved.

Keywords: accreditation, journalism education, unit standards, shorthand

\section{GRANT HANNIS}

Massey University, Wellington

7 RE REPUTATION of a journalism school among its primary stakeholders - its students, the journalism industry, and the school's host

$\perp$ academy - is based on a multitude of factors, including the achievements of the school's alumni, the faculty's professional backgrounds and standing, and the quality of the school's research output. Another factor that can help determine a school's reputation is accreditation, the endorsement of the school by some independent agency. 
The United States and the United Kingdom both have agencies that accredit university-based journalism programmes. But on both sides of the Atlantic the accreditation of journalism schools has proved a vexed question of late, with doubts raised about the benefit to journalism schools of obtaining such external endorsement. The main sticking point has been the perceived inflexibility of accreditation requirements, which have frustrated some journalism schools at a time when journalism practice is changing rapidly - particularly the rise of web-based reporting (McNair, 2010; Seamon, 2010).

New Zealand has already played out this controversy. Effectively, all new recruits in the mainstream news media in New Zealand must complete a qualification at one of the country's journalism schools in order to enter the industry. New Zealand journalism schools are accredited by an industry body, the New Zealand Journalists' Training Organisation (NZJTO). The relationship between the NZJTO and the university-based journalism programmes has been strained at times, but recently a new accord was forged, under which a more flexible method of accreditation has been developed. This article discusses that controversy and the new accreditation system that resulted. This experience is reported in the hope it may prove instructive to journalism programmes elsewhere, as they struggle to balance accreditation requirements with the need for journalism education to be able to respond in a timely fashion to changes in journalistic practice.

The author must declare his interest in this discussion. He has headed one of the university-based journalism programmes in New Zealand, Massey, since 2004 and has been a journalism educator representative on the NZJTO since 2005. He has thus experienced many of the events described below first hand.

The article begins by reviewing the debate in the United States and the United Kingdom. It then considers the situation in New Zealand, looking at the current accrediting regime and the controversy that led to it. The conclusions are then presented.

\section{Accreditation in the US and UK}

In the United States, journalism education is based in universities, some of which seek accreditation from the Accrediting Council on Education in Journalism and Mass Communications (ACEJMC). Established in 1945, ACEJMC accredits about a quarter of the approximately 400 colleges and universities offering formal programmes in journalism in the United States 
(ACEJMC, 2011a). Yet in a recent article reviewing the literature, Marc Seamon found little to distinguish accredited and non-accredited programmes' curricula (Seamon, 2010). For instance, both gave equal weight to news writing in the curricula and to critical-cultural perspectives. In some cases, Seamon argued, such as in teaching mathematical skills and convergence journalism, the research found that the inflexible accreditation requirements actually impeded curriculum development at accredited schools. Some faculties have also complained that accreditation is too time-consuming and that site teams were arrogant and unwilling to change preconceived ideas about the schools they were assessing.

Seamon noted that numerous major journalism programmes are not accredited. Observing that the University of Wisconsin decided not to seek reaccreditation, Seamon commented:

Wisconsin's rationale was that it didn't need accreditation to prove that it was a good journalism program. In fact, Wisconsin believed it could be a more effective program without the strictures attached to accreditation (Seamon, 2010, p. 11).

ACEJMC did not take kindly to Seamon's article. Ceppos (2010), a member of ACEJMC's council, described parts of the article as 'drivel' and 'mystifying', and asserted that ' $[p]$ erhaps unaccredited programs do better with convergence...[but] accrediting requirements are not to blame' (Ceppos, 2010, p. 210). Ceppos argued that some of the studies cited by Seamon were old and that the number of accredited journalism schools was at a record high of 113 .

The dominant voice in ACEJMC is that of the academy; ACEJMC's bylaws specifically state that the majority of its accrediting committee members be educators (ACEJMC, 2011b). In the United Kingdom, by contrast, the accrediting body for newspaper journalism is industry-dominated. The National Council for the Training of Journalists (NCTJ) was established in 1951. Fifteen members of its 16-person board are drawn from the media industry and NCTJ's wider membership is all drawn from the newspaper industry. NCTJ accredits more than 40 colleges, universities and other institutions to train journalists. These programmes cover training both for those wishing to enter the industry and for those already working as journalists (NCTJ, 2011a).

But, as in the United States, not all journalism programmes are 
accredited by the NCTJ and doubts have been raised about the effectiveness of accreditation. In 2007, the Association for Journalism Education, which represents journalism educators in higher-education institutions in the United Kingdom and Ireland (Association for Journalism Education, 2011), discussed whether its members should boycott the NCTJ. Among the association's complaints were that the NCTJ was irrelevant to the modern converged news industry, its accreditation requirements lacked academic rigour and there was a lack of higher-education-sector representation on the NCTJ's board (Bradshaw, 2007).

In the end, no boycott was forthcoming. However, in 2008 the well-known journalism programme at the University of Strathclyde decided it no longer wished to be accredited. Brian McNair, head of the programme at the time, said the reason was '[t] here was simply no space for the NCTJ's increasingly unrealistic demands on both staff and students' (McNair, 2010, para. 2). These demands included the teaching of shorthand and a focus on the 'old world of print journalism', rather than new media (McNair, 2010, para. 6). Free of the NCTJ curriculum, McNair said, Strathclyde's 'synergy of journalism with creative writing, humanities, and social sciences could flourish' (McNair, 2010, para. 4).

Reviewing the British debate, British journalism educator and commentator Roy Greenslade said that although there was still general support for accreditation in the United Kingdom, the issues McNair raised deserved debate (Greenslade, 2010a, 2010b). Greenslade observed that 'it's often difficult to meld many university courses with the NCTJ's course requirements' (Greenslade, 2010a, para. 12) and noted that the journalism courses at City University, London, where Greenslade teaches, are also not accredited. 'Let battle commence!' he declared (Greenslade, 2010b, para. 10).

New Zealand follows the United Kingdom model of having industry accreditation of journalism schools, and has experienced similar tensions regarding accreditation to those discussed above. However, a new accord was reached recently, allowing a more flexible industry accreditation of universitybased journalism schools to continue.

\section{Journalism education in New Zealand}

There are 10 journalism programmes in New Zealand, delivering a mix of degree and diploma courses, primarily entry-level courses (that is, for 
those students wishing to enter the industry as new recruits). There are three university-based programmes: Auckland University of Technology, Massey University and the University of Canterbury, offered in the country's three main centres of Auckland, Wellington and Christchurch respectively. All three universities offer select-entry effectively postgraduate programmes for about 20-30 students; AUT also offers an undergraduate entry-level journalism degree (Bachelor of Communication Studies) and a new Graduate Diploma in Pacific Journalism. Canterbury decided to suspend its course for the 2012 academic year, in part as a result of rebuilding work required at the university following the Christchurch earthquakes (J. Tully, personal communication, 20 March 2012). The remaining seven journalism programmes are delivered at technical institutes, ranging from one-year programmes open to all students (from school leavers through to degree graduates) to degree courses. In 2011, there were about 360 students enrolled in entry-level journalism programmes, with the universities producing about a third of the journalism graduates (see Table 1).

All 10 journalism programmes are accredited by the $\mathrm{NZJTO}^{1}$, which is largely funded by industry levies and the government. The NZJTO employs an executive director who reports to the organisation's council. The NZJTO is overwhelmingly an industry body: its council comprises 17 people, 15 of whom are representatives from various sectors of the industry (newspapers, television, radio, the unions, etc.), with two journalism-school representatives - one representing the technical institutes and the other the universities (the current author) (M. Fletcher, personal communication, 26 September 2011). The NZJTO also offers training to working journalists and is part of a larger organisation that oversees industry training throughout the print and media industry, the Communications and Media Industry Training Organisation (CMITO).

As part of accreditation, every journalism programme is required to have an industry liaison committee. This committee comprises local industry representatives and the executive director of the NZJTO, and meets regularly with faculty to discuss the progress of the course, changes to the curriculum, etc. during the year. The executive director of the NZJTO also spends a day discussing accreditation and other matters of mutual interest with the journalism educators at their annual conference.

Another accreditation requirement is that part of every journalism 


Table 1: NZ journalism school entry level enrolments, 2011
\begin{tabular}{|l|c|l|}
\hline Learning institutions & No. of students & $\begin{array}{l}\text { Percentage of } \\
\text { grand total }\end{array}$ \\
\hline Universities & & \\
\hline Auckland University of Technology & $82^{*}$ & \\
\hline Massey University & 21 & \\
\hline University of Canterbury & 20 & \\
\hline Sub-total & 123 & $34 \%$ \\
\hline Technical Institutes & & \\
\hline Aoraki Polytechnic & 30 & \\
\hline Christchurch Polytechnic Institute of Technology & 38 & \\
\hline Southern Institute of Technology & 15 & \\
\hline Waiariki Institute of Technology & 31 & \\
\hline Waikato Institute of Technology & 43 & \\
\hline Western Institute of Technology at Taranaki & 13 & \\
\hline Whitireia Community Polytechnic & 68 & \\
\hline Sub-total & 238 & $100 \%$ \\
\hline Grand total & 361 & \\
\hline
\end{tabular}

Source: NZTO, 2011. * Includes final year degree journalism students at AUT.

programme's curriculum is moderated by the NZJTO annually. The NZJTO requests a range of documentation relating to two broad areas of the curriculum (such as news gathering or media law). This material includes the assessment tasks given to the students, the marking criteria, and the marked assignments of three students - one who just passed (or failed) the assessment, and two from students who were clear passes. NZJTO assessors-usually comprising the NZJTO executive director, a CMITO staff member, two industry representatives and a journalism educator - review the material to determine if the assessments are appropriate and whether the students' work has been marked appropriately.

Although the NZJTO has a lengthy, and prescriptive, model for what must be taught at journalism schools, only the technical institutes are required to follow this to the letter. The three university programmes are only required to follow the spirit of these requirements. To understand how the situation was arrived at, we must consider the history of accreditation of journalism programmes in New Zealand. 


\section{The development of accreditation}

For many years the country's journalism training was based on industry cadetships, with only a few journalism schools - nearly all technical institutes — offering vocational journalism training (Gaunt, 1992; Thomas, 2008). There was no accreditation of any journalism programmes. The largest journalism programme was that at the Wellington Polytechnic, established in 1964. Massey University effectively took Wellington Polytechnic over in 1999, thereby acquiring the course. Similarly, the AUT course was originally offered by Auckland Technical Institute, which ultimately became Auckland University of Technology in 2000. Only the journalism programme at the University of Canterbury, which operated off and on for most of the 20th century, was always university-based.

In the late 1980s, the government instituted a new regime for education in New Zealand, the National Qualifications Framework, administered by the New Zealand Qualifications Authority, a government agency. This system continues to this day. As part of this regime, industry training organisations prepare unit standards - statements as to what a student who has achieved a given standard knows and can do-and accredit trainers to deliver these unit standards. The industry training organisations register their unit standards and qualifications comprising these standards with the New Zealand Qualifications Authority (New Zealand Qualifications Authority, 2012). Initially, the New Zealand Qualifications Authority expected university papers would also be converted to unit standards, but the universities strongly resisted this as an attack on academic freedom, and the idea was abandoned (Viskovic, 1999). That battle was a harbinger of the disputes that subsequently arose in journalism training.

The NZJTO was established in 1993 as an industry training organisation, evolving out of the earlier Journalism Training Board. It developed unit standards for the entry-level journalism courses. This process had been sparked by concerns in the industry about the variable quality of training across the journalism schools. Unit standards were seen as way of standardising the training, particularly at some of the technical institutes, which 'were often staffed by a single over-worked tutor who was grateful for the guidance the unit standards and the NZJTO provided' (Thomas, 2008, p. 23). Indeed, moderation of the smaller journalism schools at technical institutes would sometimes involve the NZJTO lobbying the host institution to supply the school with more resources (Quirke, 2003). 
The unit standards were highly prescriptive. For instance, under unit standard 10375, which covered work in a newsroom, the student had to:

1. Demonstrate knowledge of a news organisation's management structure, by describing:

- The functions, interrelationships and contribution to output of, among other activities, news gathering, production, editorial, administration, advertising, ownership and accounts

- The functions of the editorial staff, with regard to their contribution to the flow of copy

- The relevant factors in the maintenance of professional relationships in the newsroom, including working in teams, consulting and maintaining confidentiality

2. Demonstrate knowledge of work practices in the newsroom, by describing:

- The organisation of the newsroom, such as the allocating of assignments, news conferences, running the diary, liaising with photographers, and obtaining equipment

- The process of writing news, including house style, rewriting and deadlines

3. Monitor or use newsroom resources, by:

- Monitoring and describing the inward flow of news and information into the newsroom

- Taking messages accurately and speedily giving them to the intended recipients, including telephone calls, emails, faxes, written and verbal messages

- Describing the newsroom's library, files, archives, diaries, contact books, etc.

- Producing, distributing and storing copy and operating the newsroom's keyboard in line with the newsroom's requirements

4. Maintaining professional standards in the newsroom, by:

- Adhering to dress codes

- Being punctual, including observing starting and finishing times, mealtimes and deadlines

- Regularly communicating with newsroom staff

- Being familiar with the process of monitoring breaking news, such as by monitoring a range of news media including the newsroom's own news output

- Generating and logging story ideas every day.

(Source: New Zealand Qualifications Authority, 1997) 
There were a considerable number of unit standards. Once the student successfully completed the workload for the unit standard described above, for instance, the student obtained just two credits towards the 120 credits the student had to have to receive the unit-standards-based journalism qualification.

The only university course existing at the time, Canterbury, declined to teach unit standards. Reflecting the views of New Zealand universities more generally, it did not regard unit standards as an appropriate basis on which to deliver the curriculum (J. Tully, personal communication, 20 March 2012). Canterbury had long been regarded by the industry and students as one of the best, if not the best, course in the country. As the only university course, it attracted high-quality students and could afford to deploy relatively extensive resources to educate and train its students. As such, the NZJTO entered into a little-publicised special relationship with Canterbury, recognising and moderating the course even though Canterbury did not strictly speaking adhere to the unit-standards system. Canterbury later grew disenchanted with the professional quality of the NZJTO's moderation, in particular the school visit whereby the NZJTO executive director would visit the school and interview students. Following this, Canterbury refused to be moderated, a situation the NZJTO tolerated (Thomas, 2008).

When Massey and AUT arrived on the scene, both of these universities initially agreed to go on to the unit-standards framework. This was presumably because both had inherited their journalism programmes and faculty from technical institutes, which had accepted the unit standards system for some years. But as a university culture began to inculcate these two university programmes, pressure for change began. This was given greater impetus by the government establishing a new regime for the funding of research at tertiary educational institutions. This was the Performance-Based Research Fund (PBRF), under which institutions receive more funding the more high-quality academic research they produce (a system similar to the United Kingdom's Research Assessment Exercise) (Tertiary Education Commission, 2011). The PBRF encouraged the universities to require faculty members to have research qualifications and to publish research, especially in the form of peer-reviewed international academic journal articles. As many of the faculty at the Massey and AUT programmes had come from a technical-institute background, they often did not have such qualifications or academic research expertise. Gradually, staff began to obtain higher degrees or leave the programmes, to be replaced by staff with such expertise (Hannis, 2007). 
These changes led to a very public dispute erupting between the NZJTO and Massey University's journalism programme. The NZJTO's then executive director, Bill Southworth, voiced his profound scepticism about the future direction of the Massey course on a weekly national radio programme dedicated to discussing the media (Mediawatch, 2003) and in an interview for a daily national radio news programme (Morning Report, 2003). In the radio interview, Southworth said he held 'great concern' about the course's direction because, given the demands of the PBRF, the University 'tended to look first and foremost at the academic background of the people they're hiring rather than their practical newsroom experience' (Morning Report, 2003). Frank Sligo, head of Massey University's then Department of Communication and Journalism, which hosted the Massey journalism school, replied in the same programme that Massey's Journalism faculty did have extensive journalism experience, but that the 'reality for the University is that it has to try to satisfy two masters [industry and the academy]' (Morning Report, 2003). Needless to say, such a public wrangle tarnished Massey's reputation, with both students and industry representatives questioning the faculty about the course's direction.

Not long afterwards, Sligo wrote a commentary on the unit standards for Pacific Journalism Review. He condemned the unit standards for their 'extraordinary, reductionist detail' (Sligo, 2004, p. 191) and for being 'a flawed model of data-transfer, not a theory of education' (Sligo, 2004, p. 193). In the interests of academic freedom, he was happy to allow the Massey journalism school to continue to teach unit standards, but, if the journalism faculty thought the unit standards were not useful, 'it is not only their right but their duty to find better alternatives' (Sligo, 2004, p. 196). Southworth later retorted that Sligo 'was confusing an industry teaching method with the industry's right to expect that journalists have been marked at a level that it can have confidence in' (Southworth, quoted in Dow, 2004, p. 11).

Southworth made those comments in the AUT journalism school's student newspaper Te Waha Nui, but AUT was eventually to become dissatisfied with the unit standards as well. Indeed, an ambiguous relationship had developed between AUT and the NZJTO. First, some of the university's journalism courses were not fully covering the unit standards (Thomas, 2008). Second, AUT was increasingly expressing reservations with unit standards. Ruth Thomas, a senior journalism lecturer, for instance, argued that unit standards stifled innovative thinking among her students (Thomas, 2008). 
Southworth resigned from the NZJTO in 2005, and his replacement established a new suite of unit standards. These proved to be even more prescriptive than the earlier ones. That executive director soon resigned and his replacement, Mike Fletcher, the incumbent, began reviewing the unit standards yet again (NZJTO, 2009a). Around the same time, the government warned the NZJTO that it risked losing its status as an industry training organisation because it was not engaged in training those actually working in the industry (moderating journalism schools being insufficient). In response, the NZJTO merged with another industry training organisation to form the CMITO (although the NZJTO continued to operate under its old name for branding purposes), and set about offering a workplace-based training qualification, the National Diploma in Applied Journalism (CMITO, 2009; NZJTO, 2009b).

A debate then arose between the then head of the AUT programme, Martin Hirst, with the industry regarding the teaching of shorthand. Shorthand is part of the unit standards. In email correspondence between the journalism schools and the NZJTO on the subject, Hirst noted that while AUT would continue to teach shorthand, 'I also reserve my right to argue that it is an out-dated technology' (M. Hirst, personal communication, 27 August 2009). Hirst also argued that shorthand was expensive to teach and was 'a drain on budget resources that could go towards more equipment or staffing in other areas' (M. Hirst, personal communication, 27 August 2009). But the response from Mike Fletcher of the NZJTO was unequivocal: 'The industry is firm that shorthand must remain part of the J-Schools' curriculum' (M. Fletcher, personal communication, 27 August 2009). Hirst has since returned to Australia (for his discussion on the state of journalism education in Australia and New Zealand, see Hirst, 2010).

By 2009, it was clear that all the university programmes were going to leave the unit standards. A formal announcement to this effect was made by the current author at that year's conference of journalism educators (Hannis, 2009). To avoid a permanent schism between the universities and the NZJTO, an accommodation had been reached. Although the universities would not strictly speaking teach unit standards, their curricula would be informed by unit standards, because the standards cover the basic knowledge expected of new recruits into the industry. Should a university wish not to teach some aspect of unit standards, or not to undertake assessment as per a unit standard, that would be acceptable to the NZJTO on the condition that the universities did not stray too far from vocational training. 
For moderation purposes, the NZJTO would moderate the universities on the basis of their curricula and assessments, rather than against the unit standards. Each year, the NZJTO instructs all the schools to submit material pertaining to two specified unit standards. The universities supply material that approximates the material taught as the unit standard. Given this revised moderation regime, Canterbury agreed to be regularly moderated.

Since then, the relationship between the NZJTO and the university journalism programmes has proceeded relatively smoothly. In 2010, the NZJTO moderated each schools' teaching of news writing and web-based reporting, and in 2011 news gathering and news media ethics. The university programmes passed the moderation requirements in both rounds (NZJTO 2010; M. Fletcher, personal communication, 19 October 2011).

The new regime has apparently not compromised the universities' abilities to produce work-ready journalism graduates. Of late, university-trained students have set the standard in the industry's annual awards for journalism excellence. In the last five years, the top national student print journalism prize has been awarded to students who studied at a university course (Qantas Media Awards Results, 2007, 2008, 2009, 2010; Canon Media Awards, 2011).

\section{Discussion}

Accreditation can confer significant benefits on a journalism school, helping to signal to its stakeholders that its programme is of a high quality. But accreditation has become a matter of significant debate in the United States and the United Kingdom, with criticisms focussing on the inflexibility of accreditation requirements, particularly in teaching the fast-changing world of web-based journalism. This article has examined the situation in New Zealand, in the hope this experience may prove instructive in charting a way forward elsewhere.

Several general lessons can be learnt from the New Zealand experience. First, journalism courses derive value from industry input. Not only does the industry assist in teaching university students, by taking the students on workplace internships during the programme, it also employs the programmes' graduates. It seems only reasonable, then, that industry has an input into both what is taught and the nature and quality of assessment. The NZJTO's accreditation requirements have played a significant role in facilitating such industry input, such as via each programme's industry liaison committee. 
Second, in managing the relationship between the journalism school and industry, power matters. The NZJTO's power is derived from the fact it can remove a school's accreditation. When the NZJTO was established, the variability of training across the journalism schools meant some did not enjoy strong reputations. The NZJTO was therefore in a position where it could dictate the terms of the relationship with most of the journalism schools. But the NZJTO's power was circumscribed. As its mandate was to establish consistent education standards across the journalism schools, the NZJTO had an incentive to work with under-performing schools to lift their performance, rather than simply remove their accreditation. More profoundly, if a school's reputation was already very strong, the NZJTO was obliged to accredit it. That was the situation with Canterbury. As a well-resourced programme and, at the time, the only university course, Canterbury attracted high-quality students who the industry wanted to hire. The NZJTO could not ostracise Canterbury because to do so would make NZJTO accreditation appear perverse. Canterbury was therefore accredited despite the university rejecting those aspects of accreditation it did not favour. Likewise, when the NZJTO's status as an industry training organisation came under threat, it had an incentive to find a way to keep the high-profile journalism educational institutions, the universities, in the fold. Again, losing them would have undermined the NZJTO's credibility. This was because a journalism school's power is derived from its reputation, and this is based on more than just accreditation. The quality of a school's students, its faculty, and the resources at its disposal are among the other factors that determine its reputation, as the Canterbury experience testified. These other factors may play an even greater role than usual in New Zealand, in that the NZJTO accredits all the journalism schools and thus NZJTO accreditation does not differentiate the schools (in contrast with ACEJMC, for instance). When Massey and AUT entered the scene, the reputation of those programmes was enhanced by their university status, and, thus, their ability to continue to attract high-quality students. The NZJTO was therefore ultimately obliged to accommodate those universities, just as it had Canterbury.

But the universities' power is also circumscribed. The three universities have withstood industry criticism largely because they have remained vocational courses - as evidenced by their students' success at the industry awards. If there were to be a scaling back of vocational training in favour of a much greater focus on academic research or reflective study on journalism 
courses, the industry can be expected to respond swiftly. The industry's recent forthright insistence that shorthand must be taught shows there are limits to how accommodating the industry is to the academy. Likewise, shorthand is a key component of NCTJ accreditation in Great Britain (NCTJ, 2011b).

Third, personalities are important. The NZJTO's combative approach with Massey in 2003 and 2004 reflected the personality of its then executive director. He had hoped that publicly aired criticism of Massey would bring the university to heel. Although his criticisms were damaging, they were ultimately unsuccessful because they ignored the power issues discussed above. The incumbent executive NZJTO director is more accommodating and genial, and has played a key role in fashioning a new model for accreditation acceptable to all.

\section{Note}

1. Reflecting technicalities in the actual arrangements in place, some of the organisations involved differ in the terminology they employ to describe accreditation. For instance, the University of Canterbury says it is 'recognised' by the NZJTO. For the sake of simplicity, the term 'accreditation' is used in this article to cover all arrangements.

\section{References}

Accrediting Council on Education in Journalism and Mass Communications. (2011a). Frequently asked questions concerning accreditation. Retrieved on 10 February 2011, from www2.ku.edu/ acejmc/STUDENT/FAQS.SHTML

Accrediting Council on Education in Journalism and Mass Communications. (2011b). Accrediting Committee. Retrieved on 10 February 2011, from www2. $\mathrm{ku} . \mathrm{edu} / \sim$ acejmc/PROGRAM/COMMITTEELIST.SHTML

Association for Journalism Education. (2011). What is the AJE? Retrieved on January 2011, from www.ajeuk.org/about/

Bradshaw, P. (2007). Boycott the NCTJ? If only. Retrieved on 1 January 2011, from http://onlinejournalismblog.com/2007/09/12/the-nctj-marketing-not-education/

Canon Media Awards. (2011). Retrieved on 5 October 2011, from www.canonmediaawards.co.nz

Ceppos, J. (2010). To the editor [Letter to the editor]. Journalism \& Mass Communication Educator, 65(2), pp. 210-211.

Communications and Media Industry Training Organisation. (2009). Overview of New Zealand journalism training requirements. Wellington: Communications and Media Industry Training Organisation. 
Dow, J. (2004, September 6). JTO defends unit standards. Te Waha Nui, p. 11.

Gaunt, P. (1992). Making the newsmakers: International handbook of journalism training. Westport, Connecticut: Greenwood Press.

Greenslade, R. (2010a). NCTJ supporters outgun detractors, but that isn't the end of the argument. Retrieved on 7 December 2010, from www.guardian.co.uk/media/ greenslade/2010/sep/15/journalism-education-cityuniversity

Greenslade, R. (2010b). Do journalists really need the NCTJ certificate any longer? Retrieved on 7 December 2010, from www.guardian.co.uk/media/greenslade/2010/ sep/15/journalism-education-cityuniversity

Hannis, G. (2007). New Zealand's PBRF experience and the implications for Australia's Research Quality Framework. Australian Journalism Review, 29(1), pp. 13-26.

Hannis, G. (2009, December). New Zealand journalism education in a PBRF world: Responding to the challenge of 2012. Paper presented at the Journalism Education Association of New Zealand conference.

Hirst, M. (2010). Journalism education 'down under': A tale of two paradigms, Journalism Studies, 11(1), pp. 83-98.

McNair, B. (2010). Why the course at Strathclyde [sic]. Retrieved on 5 December 2010, from www.allmediascotland.com/blog/0/123/Why\%20the\%20Course $\% 20$ at $\% 20$ Strathclyde

Mediawatch. (2003, November 30). The academic capture of journalism schools [Transcription of radio broadcast]. Retrieved on 12 February 2011, from www.radionz.co.nz/national/programmes/mediawatch/archive/2003/20031130

Morning Report. (2003, October 24). [Radio broadcast]. Wellington: Radio New Zealand.

National Council for the Training of Journalists. (2011a). About us. Retrieved on 20 March 2011, from www.nctj.com/about-us/

National Council for the Training of Journalists. (2011b). Shorthand. Retrieved on 20 March 2011, from www.nctj.com/qualifications/shorthand/

New Zealand Journalists' Training Organisation. (2009a). NZJTO strategic training plan. Wellington: New Zealand Journalists' Training Organisation.

New Zealand Journalists' Training Organisation. (2009b, February 17). Minutes of the Journalists Training Organisation Sector Committee meeting. Wellington: New Zealand Journalists' Training Organisation.

New Zealand Journalists' Training Organisation. (2010). Moderation. Wellington: New Zealand Journalists' Training Organisation.

New Zealand Journalists' Training Organisation. (2011). J-school statistics. Wellington: New Zealand Journalists' Training Organisation.

New Zealand Qualifications Authority. (1997). National qualifications, level 5. Wellington: New Zealand Qualifications Authority.

New Zealand Qualifications Authority. (2012). Standards. Retrieved on 23 March 2012, from www.nzqa.govt.nz/framework/about.html

Qantas Media Awards Results. (2007). Retrieved on 13 February 2011, from www.scoop.co.nz/stories/BU0705/S00439.htm 
Qantas Media Awards Results. (2008). Retrieved on 13 February 2011, from www. scoop.co.nz/stories/BU0805/S00188.htm

Qantas Media Awards Results. (2009). Retrieved on 13 February 2011, from www. scoop.co.nz/stories/BU0905/S00438.htm

Qantas Media Awards Results. (2010). Retrieved on 25 June 2011, from www. qantasmediaawards2010.co.nz

Quirke, M. (2003, October 8). Changes too late for students. The Dominion Post, p. 8.

Seamon, M. (2010). The value of accreditation: An overview of three decades of research comparing accredited and unaccredited journalism and mass communication programs. Journalism \& Mass Communication Educator, 65 (1), pp. 10-20.

Sligo, F. (2004). NZ journalism unit standards: Are they still needed? Pacific Journalism Review, 10(1), pp. 191-199.

Tertiary Education Commission. (2011). Performance-Based Research Fund. Retrieved on 20 October 2011, from www.tec.govt.nz/Funding/Fund-finder/PerformanceBased-Research-Fund-PBRF-/

Thomas, R. (2008). The making of a journalist: The New Zealand way. Unpublished doctoral dissertation, Auckland University of Technology, Auckland.

Viskovic, A. (1999). Student-centred learning: Does the New Zealand national qualifications framework promote self-directed learning? Retrieved 1 January 2010, from http://herdsa.org.au/branches/vic/Cornerstones/authorframeset.html

Dr Grant Hannis heads the journalism programme at Massey University in Wellington, New Zealand. He has also been a member of the New Zealand Journalists' Training Organisation (NZJTO) council, representing journalism educators, for many years. In 2010, Dr Hannis spent six months researching and teaching journalism at San Francisco State University as a Fulbright Senior Scholar.

G.D.Hannis@massey.ac.nz 